\title{
Association of 16SrII-C and 16SrII-D subgroup phytoplasma strains with witches' broom disease of Parthenium hysterophorus and insect vector Orosius albicinctus in India
}

\author{
Amit Yadav $^{1} \cdot$ Vipool Thorat $^{1} \cdot$ Udhav Bhale $^{2} \cdot$ Yogesh Shouche $^{1}$
}

Received: 21 March 2015 / Accepted: 11 October 2015 /Published online: 18 October 2015

(C) Australasian Plant Pathology Society Inc. 2015

\begin{abstract}
Parthenium weed (Parthenium hysterophorus, Asteraceae) is a common, invasive weed found throughout the Indian subcontinent, Africa, America and Australia. The observed disease, Parthenium Witches' Broom (PWB), characterised by phylloidy, stunting and prolific branching was observed during a field survey conducted between September 2014 to June 2015. PWB phytoplasma was detected in all symptomatic plant samples and in the previously reported insect vector, Orosius albicinctus belonging to family Cicadellidae (subfamily Deltocephalinae) and other Hemipteran insect samples by amplifying its 16S rRNA gene. To our knowledge, this is the first report of a ' $\mathrm{Ca}$. Phytoplasma aurantifolia'- related strains associated with witches' broom disease of P. hysterophorus and insect vector Orosius albicinctus.
\end{abstract}

Keywords ' $C a$. Phytoplasma aurantifolia' $\cdot 16 \mathrm{Sr}$ II group · Parthenium hysterophorus · Cicadellidae · Deltocephalinae . Insect Vectors · Orosius albicinctus

Amit Yadav

amityadav@nccs.res.in

Vipool Thorat

vipoolthorat14@gmail.com

Udhav Bhale

drunbhale2012@gmail.com

Yogesh Shouche

yogesh@nccs.res.in

1 Microbial Culture Collection, National Centre for Cell Science, Pune 411007, India

2 Department of Botany, Arts, Science and Commerce College, Naldurg, Osmanabad 413602, India
Parthenium hysterophorus is a widely spread and exotic weed in India. It is known as one of the most dangerous weeds and several attempts have been made to control its spread by various methods (Sileshi and Tessema 2010). Foliar leachates from Parthenium have been demonstrated to have allelopathic effects, including low germination rates and reduced yields in several pulse crops (Evans 1997). Parthenium hysterophorus is a known secondary host for many bacterial, viral diseases and insect pests of crop plants (Lakshmi and Srinivas 2007). It is known to harbour the faba bean phyllody phytoplasma (Taye et al. 2004), Aster Yellow phytoplasma (Raj et al. 2008), Pseudomonas solanacearum (Kishun and Chand 1998), Xanthomonas campestris pv. Phaseoli (Evans 1997), Groundnut bud necrosis virus (Prasada et al. 2005) and Tomato yellow leaf curl virus (Govindappa et al. 2005).

Parthenium weed has been shown to be an alternative host of black bean aphid (Aphis fabae) in southern India and scarab beetle (Pseudoheteronyx sp.), which is a pest of sunflower in central Queensland, Australia (Evans 1997). Parthenium hysterophorus also serves as a reservoir for Lepidopteran and Hemipteran insect pests of crop plants between cropping seasons (Sileshi et al. 2008). Another insect pest, Liriomyza trifolii which oviposit on P. hysterophorus in Texas, USA is a known pest of bell pepper (Capsicum annuum, Solanaceae) (Chandler and Chandler 1988).

Parthenium hysterophorus plants typically showing symptoms of phylloidy were observed during a field survey conducted between September 2014 to June 2015. Plant samples were collected from barren lands, dumping grounds and farmlands around Pune, Satara and Naldurga (Osmanabad) cities of Maharashtra, India. Simultaneously, insect samples, mainly plant hoppers and leafhoppers (targeting Cicadellidae family), were collected using a white light trap as previously described (Steiner and Hauser 2010), as they are known plant sapfeeders and vectors of phytoplasmas (Wilson and Weintraub 
2007). A total of 48 insect samples were collected in eppendorf tubes and preserved in $95 \%$ ethanol until DNA extraction.

Two grams of compound leaves from symptomatic and asymptomatic plants (Fig. 1) were used for total DNA extraction using the CTAB method (Doyle and Doyle 1990). Total DNA extraction from collected insect samples were carried out using DNeasy Blood and Tissue Kit (Qiagen, Germany) following the manufacturer's protocols, using the whole individual as starting material.

To determine the presence of phytoplasma in $P$. hysterophorus and insect samples, the PCR reaction was performed with $1 \mathrm{X}$ PCR buffer, $1.5 \mathrm{mM} \mathrm{MgCl}_{2}, 50 \mathrm{ng}$ DNA from either plant or insect samples, $200 \mu \mathrm{M}$ of dNTPs, 1 U of Taq DNA Polymerase (Invitrogen, Germany), $0.5 \%$ DMSO, $2 \mu$ g per $\mu$ BSA, $1 \mu \mathrm{M}$ of P1 and P7 primers (Smart et al. 1996) followed by nested PCR primer R16F2n and R16R2 (Gundersen and Lee 1996). For nested PCR reaction, 10 fold diluted template generated by $\mathrm{P} 1 / \mathrm{P} 7$ primers were used. PCR amplification of partial mitochondrial COX I (Cytochrome Oxidase I, COI) gene was performed using universal invertebrate primers, $\mathrm{HCO}$ and LCO (Folmer et al. 1994). All purified phytoplasma 16S rRNA gene PCR products were sequenced directly by using primers viz. 343R, 704F, 907R, 1028F (Baker et al. 2003), R16F2n, R16R2 while COI gene was sequenced directly using LCO and HCO primers.

The obtained 16S rRNA sequences were then analysed using online databases viz. EzTaxon database (Kim et al. 2012) and GenBank, using NCBI-BLAST (Altschul et al. 1990) to find the closest match. COI gene sequences were compared in Barcode of Life (BOLD) database. All obtained sequences were deposited in the GenBank database. The phylogenetic tree based on R16F2n and R16R2 sequence was computed by neighbour-joining method using MEGA $6^{\circledR}$ software package (Tamura et al. 2013) with 1000 bootstrap replications. The genetic distances and similarities were calculated by the Tamura-Nei method.

All symptomatic $P$. hysterophorus samples showed positive amplification of phytoplasma 16S rRNA gene using P1, P7 and nested R16F2n, R16R2 primer pairs. No amplification was observed in DNA isolated from asymptomatic plants.

Phytoplasma 16S rRNA gene sequences obtained from symptomatic P. hysterophorus samples viz. PR01 to PR06 (GenBank accession numbers LN879437, LN878982, LN879438 to LN879441 respectively) showed $99.3 \%$ similarity with a ' $\mathrm{Ca}$. Phytoplasma aurantifolia' strain WBDL (U15442) when compared using the EzTaxon 16S rRNA database. Alternatively, NCBI-BLAST results showed $100 \%$ sequence similarity with Sesame Phylloidy Phytoplasma (KF322278), Coconut Phytoplasma (JQ868437), Soybean witches'-broom phytoplasma (HQ840717), Cactus Witches'Broom phytoplasma (EU099565) and Parthenium Virescence
Phytoplasma (KP899066); all related to ' $\mathrm{Ca}$. Phytoplasma aurantifolia' species. However, samples PR07 and PR08 (GenBank accession numbers LN879442 and LN879443) showed 98.78 \% sequence similarity with ' $\mathrm{Ca}$. Phytoplasma aurantifolia' strain WBDL (U15442) in EzTaxon database while NCBI-BLAST results showed $100 \%$ sequence similarity with Scaevola witches'-broom phytoplasma (AB257291) and Eggplant phytoplasma (JX441321) indicating that genetically different strains are associated with $P$. hysteroporous. These two strains showed $100 \%$ sequence similarity with 'Ca. Phytoplasma australasia' strain Carica papaya (Y10097) and over $99.9 \%$ similarity with Parthenium phytoplasma sequences deposited in GenBank database (KJ676961 and KC855731) from various places in India (unpublished).

The virtual RFLP (Zhao et al. 2009) pattern derived from the PWB Phytoplasma sequences PR01, PR03 and PR04 (LN879437 to LN879439) was found similar to a reference sequence of Cactus witches'-broom phytoplasma (AJ293216) with a similarity coefficient of 0.99 , confirming PWB phytoplasma belong to 16 SrII group, subgroup C, while PWB Phytoplasma sequences of strains PR07 (LN879442) and PR08 (LN879443) belonged to 16SrII group, subgroup D. In the present study, we found two phytoplasma subgroup strains (16SrII- C and D) showed similar phenotypic symptoms but showed sequence similarity of $98.6 \%$. It is important to note that these samples were collected from an area where phytoplasma strains related to ' $\mathrm{Ca}$. Phytoplasma aurantifolia' were dominant among Parthenium plants. These strains also showed phylogenetic similarity with Bamboo Witches' Broom (Yadav et al. 2015) and Tephrosia Witches broom Phytoplasma (Yadav et al. 2014), all belonging to $16 \mathrm{Sr}$ II group, notably collected from the same geographic regions (Fig. 2). Overall, ' $\mathrm{Ca}$. Phytoplasma aurantifolia' is known to infect more than 55 plant species reported from 24 countries as per over $15016 \mathrm{~S}$ ribosomal RNA records found in GenBank database. The phylogenetic tree constructed based on R16F $2 \mathrm{n}$ and R16R2 sequences also confirmed the genetic variability among the phytoplasma strains studied (Fig. 2).

Leafhoppers and plant hoppers are pests of many temperate and tropical crops which cause significant yield losses and increased mortality in infected crop plants due to phytoplasmas vectored by them. Knowledge of the mechanisms of phytoplasma transmission is critical for understanding of the epidemiology of diseases caused by them in crop plants and secondary hosts. Among the 48 insects collected, we could successfully amplify and sequence COI gene of 45 samples (GenBank Accession numbers, LN878983 to LN879027). The identification results of these insects are given in Table 1. We could identify 7 insect species from 6 families based on COI gene sequences and delineated them to their taxonomic designation. However, 10 of them could not be distinguished beyond family level and 5 of them could not be distinguished beyond phylum level (Table 1). The 
Fig. 1 The excised branch of Parthenium hysterophorus showing typical witches' broom symptoms after infection of 'Candidatus Phytoplasma aurantifolia' at Naldurg, India (a, b and $\mathbf{c}$ ), asymptomatic branch of Parthenium hysterophorus plant (d)

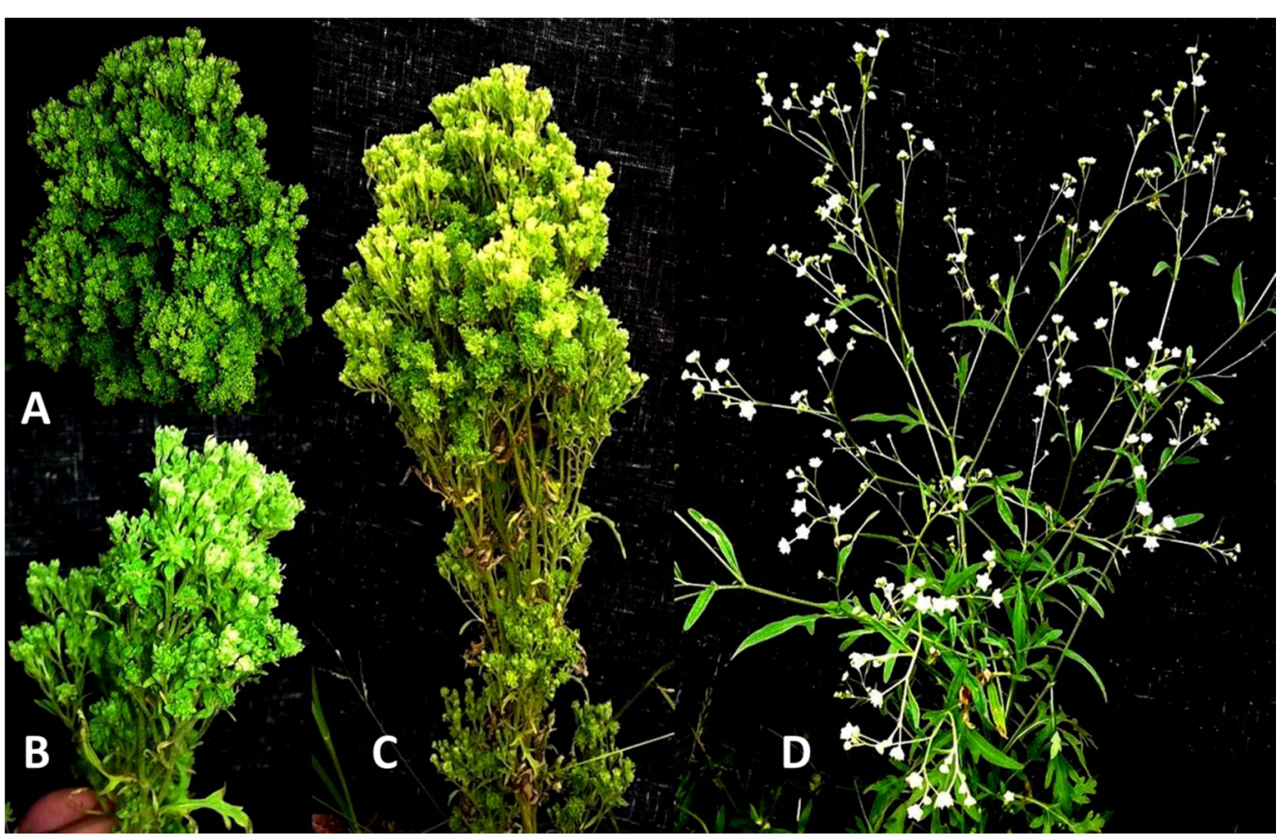

Fig. 2 Phylogenetic tree constructed based on 16S rRNA sequences showing the relationships between the Parthenium Witches' Broom Phytoplasma with phytoplasmas strains reported earlier as being associated with Parthenium hysterophorus and with other reference strains.

Symbol $®$ denotes strains of phytoplasma species found associated with Parthenium hysterophorus from current and earlier studies. The evolutionary history was inferred using the Neighbor-Joining method, with the bootstrap values

(1000 replicates) shown next to the branches. The evolutionary distances were computed using the Tamura-3 Parameter method using MEGA6 (Tamura et al. 2013). The 16S rRNA gene sequence of Acholeplasma laidlawii (M23932) was used as out group

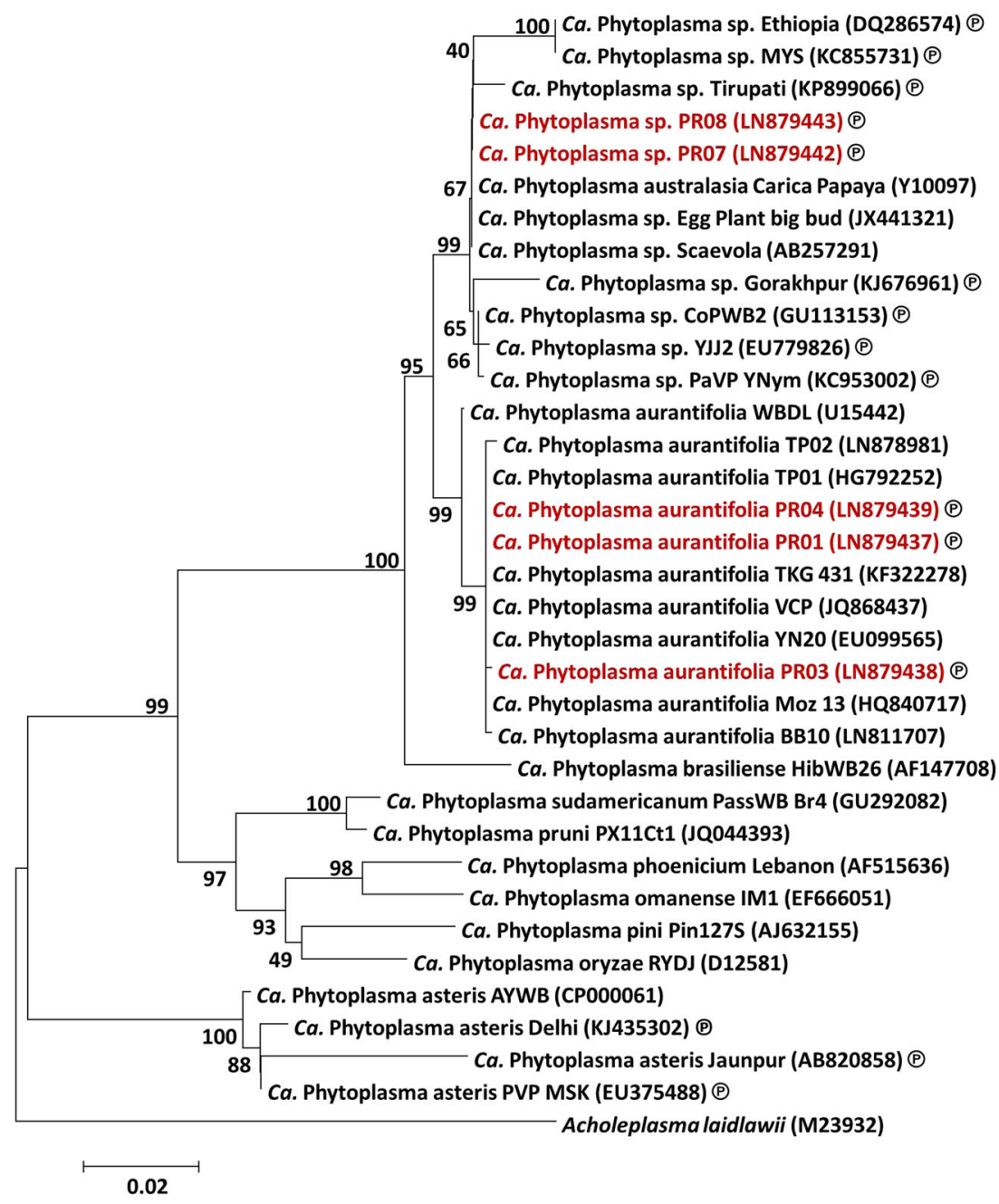


Table 1 List of Insect Samples collected from Parthenium hysterophorus dominated sites of vegetation during June- July 2015

\begin{tabular}{|c|c|c|c|c|}
\hline $\begin{array}{l}\text { Closest match } \\
\text { (BOLD Database) }\end{array}$ & Percent similarity & No of samples & PCR positives & Accession No. (partial COI gene) \\
\hline \multicolumn{5}{|l|}{ Hemiptera } \\
\hline \multicolumn{5}{|l|}{ Unknown Hemiptera } \\
\hline Unidentified species 1 & 85.26 & 1 & 1 & LN879020 \\
\hline Unidentified species 2 & 86.79 & 1 & 0 & LN879024 \\
\hline Unidentified species 3 & 86.97 & 1 & 1 & LN878994 \\
\hline Unidentified species 4 & 87.54 & 3 & 3 & LN878995, LN879011, LN879022 \\
\hline Unidentified species 5 & 85.93 & 1 & 1 & LN879016 \\
\hline \multicolumn{5}{|l|}{ Cicadellidae } \\
\hline Exitianus indicus & 100 & 2 & 2 & LN878998, LN879017 \\
\hline Orosius albicinctus & 100 & 1 & 1 & LN879006 \\
\hline Unidentified species 1 & 99.85 & 4 & 4 & LN879018, LN879019, LN879012, LN879021 \\
\hline Unidentified species 2 & 99.1 & 2 & 1 & LN879009, LN878985 \\
\hline Unidentified species 3 & 98.31 & 2 & 2 & LN879014, LN879015 \\
\hline Unidentified species 4 & 99.68 & 1 & 0 & LN879005 \\
\hline Unidentified species 5 & 99.85 & 2 & 2 & LN879013, LN878991 \\
\hline Unidentified species 6 & 99.85 & 1 & 0 & LN879010 \\
\hline Unidentified species 7 & 100 & 1 & 1 & LN878993 \\
\hline \multicolumn{5}{|l|}{ Cydnidae } \\
\hline Geotomus sp. & 98.1 & 1 & 0 & LN878984 \\
\hline \multicolumn{5}{|l|}{ Fulgoridae } \\
\hline Unidentified species 1 & 96.55 & 1 & 0 & LN878987 \\
\hline Unidentified species 2 & 97.42 & 1 & 1 & LN878997 \\
\hline Unidentified species 3 & 97.71 & 2 & 0 & LN878999, LN879001 \\
\hline \multicolumn{5}{|l|}{ Lygaeidae } \\
\hline Nysius plebeius & 100 & 3 & 3 & LN878996, LN879003, LN879008 \\
\hline \multicolumn{5}{|l|}{ Membracidae } \\
\hline Leptocentrus sp. & 100 & 3 & 0 & LN879025, LN879026, LN879027 \\
\hline \multicolumn{5}{|l|}{ Miridae } \\
\hline Taylorilygus apicalis & 100 & 10 & 10 & $\begin{array}{l}\text { LN878983, LN878986, LN878988, LN878989, } \\
\text { LN878990, LN878992, LN879002, } \\
\text { LN879004, LN879007, LN879023 }\end{array}$ \\
\hline Trigonotylus tenuis & 100 & 1 & 0 & LN879000 \\
\hline
\end{tabular}

difficulty in identifying Hemipteran pests demand the requirement for the development of systemic DNA barcoding efforts which will help in identifying them at their various stages of development and facilitate the protection measures to be taken at appropriate stages of plant growth.

From the survey and sampling, it was clear that Taylorilygus apicalis (Miridae) was dominating the insect fauna followed by members of Cicadellidae family. Insects Taylorilygus apicalis (Miridae), Exitianus indicus, Orosius albicinctus (Cicadellidae), Nysius plebeius (Lygaeidae) and other unidentified Hemipteran insects tested positive for phytoplasma presence (Table 1) in phytoplasma specific PCR assays. Orosius albicinctus has been reported previously as a vector of alfalfa witches' broom (Salehi et al. 1995), cucumber phyllody (Azadvar et al. 2005), garden beet witches' broom
(Mirzaie et al. 2007) and sesame phyllody (EsmailzadehHosseini et al. 2007) which suggest its role in transmitting PWB phytoplasma. Exitianus indicus were reported as putative phytoplasma vectors in sugarcane (Kumar et al. 2015). It is important to note that the presence of phytoplasmas (16Sr II group) found in this study were also found in Tephrosia perpurea and Dendrocalamus strictus (Yadav et al. 2014 and 2015) which indicates transmission of these strains through putative common insect vector(s). The presence of phytoplasma DNA in most of the tested Hemipteran insects indicated that these insects are reservoirs for phytoplasma and are its putative vectors. However, vectoring capability can be established further by transmission assays. The insects from Cicadellidae family had been reported as phytoplasma vectors worldwide and the probability is that the number will increase 
with the additional transmission studies. Barcoding and systematics of insect pests from Indian farms in various crops and weeds needs immediate and serious attention. Results obtained after PCR screening of Hemipteran, especially Cicadellidae insects demands in depth studies in the finding vectoring ability of these insects.

Other DNA sequences related to this study are deposited in GenBank database with accession numbers LN879028 to LN879031, LN811709 and LN879033.

Acknowledgments Authors acknowledge the funding by the Department of Biotechnology (DBT), Government of India; Microbial Culture Collection Project Grant No. BT/PR10054/NDB/52/94/2007.

\section{References}

Altschul SF, Gish W, Miller W, Myers EW, Lipman DJ (1990) Basic local alignment search tool. J Mol Biol 215:403-410

Azadvar M, Hoseini Pour A, Salehi M, Taghizadeh M (2005) Etiology and transmission of cucumber phyllody and molecular detection of the associated phytoplasma. The 4th National Biotechnology Congress, Kerman, 2005:241

Baker G, Smith JJ, Cowan DA (2003) Review and re-analysis of domainspecific 16S primers. J Microbiol Methods 55(3):541-555

Chandler LD, Chandler JM (1988) Comparative host suitability of bell pepper and selected weed species for Liriomyza trifolii (burgers). South West Entomol 13:137-146

Doyle J, Doyle J (1990) Isolation of plant DNA from fresh tissue. Focus 12:13-15

Esmailzadeh-Hosseini SA, Mirzaie A, Jafari-Nodooshan A, Rahimian H (2007) The first report of transmission of a phytoplasma associated with sesame phyllody by Orosius albicinctus in Iran. Australas Plant Dis Notes 2:33-34

Evans HC (1997) Parthenium hysterophorus: a review of its weed status and the possibilities for biological control biocontrol. News Inf 18:89-98

Folmer O, Black M, Hoeh W, Lutz R, Vrijenhoek R (1994) DNA primers for amplification of mitochondrial cytochrome c oxidase subunit I from diverse metazoan invertebrates. Mol Mar Biol Biotechnol 3:294-299

Govindappa MR, Chowda Reddy RV, Devaraja CJ, Rangaswamy KT, Muniyappa V (2005) Parthenium hysterophorus: a natural reservoir of tomato leaf curl begomovirus. In: Chandrashekar SC, Kiran KVK, Jayaram KA, Prabhakara STK (eds) Second international conference on Parthenium management ramachandra PTV, nanjappa $\mathrm{HV}$, devendra $\mathrm{R}$, manjunath a, subramanya. University of Agricultural Sciences, Bangalore, India, pp. 80-82

Gundersen D, Lee IM (1996) Ultrasensitive detection of phytoplasmas by nested-PCR assays using two universal primer pairs. Phytopathol Mediterr 5:144-151

Kim OS, Cho YJ, Lee K, Yoon SH, Kim M, Na H, Park SC, Jeon YS, Lee JH, Yi H, Won S, Chun J (2012) Introducing EzTaxon-e: a prokaryotic 16S rRNA gene sequence database with phylotypes that represent uncultured species. Int J Syst Evol Microbiol 62:716-721

Kishun R, Chand R (1998) New collateral hosts for Pseudomonas solanacearum. Indian J Mycol Plant Pathol 17:237
Kumar S, Jadon V, Tiwari AK, Rao G (2015) Exitianus indicus (distant): a putative vector for 'Candidatus phytoplasma cynodontis' in India. Phytopathogenic Mollicutes 5(1):51-52

Lakshmi C, Srinivas CR (2007) Parthenium: a wide angle view. Indian J Dermatol Venereol Leprol 73:296-306

Mirzaie A, Esmailzadeh-Hosseini SA, Jafari-Nodoshan A, Rahimian H (2007) Molecular characterization and potential insect vector of a phytoplasma associated with garden beet witches' broom in Yazd, Iran. J Phytopathol 155:198-203

Prasada RRD, Govindappa VJ, Devaraja MR, Muniyappa V (2005) Role of Parthenium in perpetuation and spread of plant pathogens. In: Chandrashekar SC, Kiran KVK, Jayaram KA, Prabhakara STK (eds) Proceedings of the second international conference on Parthenium management ramachandra PTV, nanjappa HV, devendra R, manjunath a, subramanya. University of Agricultural Sciences, Bangalore, India, pp. 65-72

Raj S, Khan C, Snehi S, Kumar S, Mall S, Rao G (2008) First report of phytoplasma 'Candidatus phytoplasma asteris' (16SrI) from Parthenium hysterophorus L showing symptoms of virescence and witches'-broom in India. Aust Plant Dis Notes 3:44-45

Salehi M, Izadpanah K, Nesbat F (1995) Etiology, transmission and host range of alfalfa witches broom in southern Iran. Iranian J Plant Pathol 31:1-9

Sileshi G, Schroth G, Rao MR, Girma H (2008) Weeds, diseases, insect pests and tritrophic interactions in tropical agroforestry. In: Batish DR, Kohli RK, Jose S, Singh HP (eds) Ecological basis of agroforestry. CRC Press, USA, pp. 73-94

Sileshi GW, Tessema T (2010) Weed suppression in legume crops for stress management. In: Yadav SS, McNeil DL, Redden R, Patil SA (eds) Climate change and management of cool season grain legume crops. Springer, USA, pp. 243-282

Smart C, Schneider B, Blomquist C, Guerra L, Harrison N (1996) Phytoplasma-specific PCR primers based on sequences of 16S-23S rRNA spacer region. Appl Environ Microbiol 62: 2988-2993

Steiner A, Hauser C (2010) Recording insects by light-traps. Manual on field recording techniques and protocols for all taxa biodiversity inventories and monitoring. Eds Jutta Eymann, Jerome Degreef, Christoph Hauser, Juan Carlos Monje, Yves Samyn and Didier Vanden Spiegel Publishers. ABC Taxa, In, pp. 400-422

Tamura K, Stecher G, Peterson D, Filipski A, Kumar S (2013) MEGA6: molecular evolutionary genetics analysis version 60. Mol Biol Evol 30:2725-2729

Taye T, Obermeier C, Einhorn G, Seemüller E, Büttner C (2004) Phyllody disease of Parthenium weed in Ethiopia. Pest Manag J Ethiop 8:39-50

Wilson MR, Weintraub PG (2007) An introduction to auchenorrhyncha phytoplasma vectors. Bulletin of Insectol 60:177-178

Yadav A, Bhale U, Thorat V, Shouche Y (2014) First report of new subgroup 16SrII- M 'Candidatus phytoplasma aurantifolia' associated with 'witches broom' disease of Tephrosia purpurea in India. Plant Dis 98(7):990

Yadav A, Thorat V and Shouche Y (2015) 'Candidatus Phytoplasma aurantifolia' (16SrII group) associated with Witches' Broom disease of Bamboo (Dendrocalamus strictus) in India. Plant Dis DOI: 101094/PDIS-05-15-0534-PDN

Zhao Y, Wei W, Lee IM, Shao J, Suo X, Davis R (2009) Construction of an interactive online phytoplasma classification tool, iPhyClassifier and its application in analysis of the peach X-disease phytoplasma group (16SrIII). Int J Syst Evol Microbiol 59:2582-2593 